\title{
Assessment on the characteristics of river kodayar with reference to Physico-chemical parameters
}

\author{
V.Sreeja ${ }^{1}$ and A.Ramalingom Pillai ${ }^{2}$ \\ ${ }^{1}$ (Chemistry, St.Xavier's Catholic College of Engineering, India) \\ ${ }^{2}$ (Chemistry, Lekshmipuram College of Arts and Science, India)
}

\begin{abstract}
The physico-chemical parameters of water samples of Kodayar River collected across few stations were assessed. The parameters like temperature (T), electrical conductivity (EC), total dissolved solids (TDS), dissolved oxygen (DO), biological oxygen demand (BOD), total hardness (TH), total alkalinity (TA), Sodium $(\mathrm{Na})$, Potassium (K), Chloride $(\mathrm{Cl})$, Nitrate $\left(\mathrm{NO}_{3}^{-}\right)$, Phosphate $\left(\mathrm{PO}_{4}{ }^{3-}\right)$ and Sulphate $\left(\mathrm{SO}_{4}{ }^{2-}\right)$ was determined. The results were compared with standards prescribed by WHO (1973) and ISI (10500-91). It was found that the water samples were not much contaminated and fit for domestic purposes. Few parameters in some of the selected stations were found to be higher and preventive measures should be adopted for quality water for domestic utilization.
\end{abstract}

Key words: Kodayar River, Physico-chemical parameters, pollution, Surface water.

\section{Introduction}

Water is a precious resource on our earth and is a vital component for human being and animals for their day today survival. Its quality is likely to change day by day and from source to source. Any change in the natural quality may disturb the equilibrium system and would become unfit for designated uses [1]. Presence of safe and reliable drinking water is a prerequisite for a stable community.

As water supports human life in a positive way, its negative effect is due to the contamination of foreign materials present beyond the permissible limits. In India most of the population depends on surface water. The ground water is believed to be comparatively free from pollution than surface water [2].

Water quality has become an important water resource issue due to rapid increase in population, industrialization, unplanned urbanization, discharge of pollutants and much use of fertilizers and pesticides. During the last decade it was observed that the surface water gets polluted because of increased human activities $[3,4,5]$.

Kodayar River is the major river system in KanyaKumari district. It originates at Muthukuzivayal plateau of Valiamalai hill and travels through forest land and stored at Pechiparai dam. Finally it drains in to Arabian Sea at Thengapatnam. The outlet from small cottage industries like brick production units, coir industry, rubber processing units and sand mining activities and also the discharge of human and animal wastes deteriorate the water quality.

The present study is to assess and interpret the surface water quality of kodayar river system across few stations like Pechiparai (S1), Chitharal (S2), Melpuram (S3), Kuzithurai (S4), Othachikotai (S5), Palugal (S6) and Thengapatnam (S7) due to their utility by human and other domestic activities. In this paper an attempt has been made to assess the physico-chemical properties of surface water like temperature (T), electrical conductivity (EC), total dissolved solids (TDS), dissolved oxygen (DO), biological oxygen demand (BOD), total hardness (TH), total alkalinity (TA), Sodium (Na), Potassium (K), Chloride $(\mathrm{Cl})$, Nitrate $\left(\mathrm{NO}_{3}{ }^{-}\right)$, Phosphate $\left(\mathrm{PO}_{4}{ }^{3-}\right)$ and Sulphate $\left(\mathrm{SO}_{4}{ }^{2-}\right)$. The analyzed data were compared with standard values recommended by WHO [6].

\section{Materials and methods}

The samples were collected from all the 7 stations for physico-chemical examinations, different methods of collection and handling were adopted based on standard procedures [7]. The samples were collected in plastic cans of 5 liter capacity without any air bubbles. The temperatures of the samples were measured in the field itself at the time of sample collection. The study period was from June 2010 to June 2011. Standard methods were used for the analysis of various water quality parameters $[8,9,10]$. All the reagents used were AR grade and double distilled water was used for the preparation of solutions. 


\section{Results and discussion}

3.1. Temperature (T)

Temperature is a very important factor for aquatic life. It controls the rate of metabolic and reproductive activities of aquatic organisms. Temperature in the study area varied from $28^{\circ} \mathrm{C}$ to $30^{\circ} \mathrm{C}$. Besides due to climatic changes there was no significant decrease or increase in temperature.

3.2. $\mathrm{pH}$

$\mathrm{pH}$ is an indicator of acidic or alkaline condition of water. Most forms of aquatic life tend to be very sensitive to $\mathrm{pH}$. The standard for any purpose in terms of $\mathrm{pH}$ is $6.5-8.5$. The $\mathrm{pH}$ values of water samples were in the range of 7.01-7.26 and 7.40 in $\mathrm{S}_{7}$.

3.3. Electrical Conductivity (EC)

EC is a measure of water capacity to convey electric current. It signifies the amount of total dissolved solids in water [11]. EC values of the water samples were in the range of $50.33 \mu \mathrm{S} / \mathrm{cm}-414.45 \mu \mathrm{S} / \mathrm{cm}$ and $4236.67 \mu \mathrm{S} / \mathrm{cm}$ in $\mathrm{S}_{7}$.

3.4. Total Dissolved Solids (TDS)

TDS is used to estimate the quality of drinking water, because it represents the amount of ions in water. If TDS values are too high or too low, the growth of many aquatic lives is affected. High concentration of TDS also reduces water clarity, contribute to decrease in photosynthesis, combine with toxic compounds and heavy metals lead to an increase in water temperature. TDS values were in the range of $48.74-179.44 \mathrm{mg} / \mathrm{l}$ and $1156.46 \mathrm{mg} / \mathrm{l}$ in $\mathrm{S}_{7}$. These values were within the prescribed limit, but compared to the seven stations higher values were found in sites $S_{6}$ and $S_{7}$.

3.5. Dissolved Oxygen (DO)

DO is a very important indicator of water body's ability to support aquatic life. They also indicate the degree of pollution in water bodies. The threshold limit for DO is $5 \mathrm{mg} / \mathrm{l}$ in drinking water and should be greater than $5 \mathrm{mg} / \mathrm{l}$ to be used for agricultural purposes [12]. DO values varied from $5.47-5.9 \mathrm{mg} / \mathrm{l}$ and $4.71 \mathrm{mg} / 1$ in $\mathrm{S}_{7}$. All the sites were in the prescribed limit.

3.6. Biological Oxygen Demand (BOD)

$\mathrm{BOD}$ is the measure of the amount of food for bacteria that is found in water. It determines the strength, in terms of oxygen, to stabilize domestic and industrial wastes [13]. BOD values ranges from $2.45 \mathrm{mg} / \mathrm{l}$ to $3.21 \mathrm{mg} / \mathrm{l}$ and $1.98 \mathrm{mg} / \mathrm{l}$ in $\mathrm{S}_{7}$. The values lie within the permissible limit of Indian Standard which may be used as drinking water after disinfection (CPCB, 1978-79) [14]. However BOD values $>3 \mathrm{mg} / \mathrm{l}$ indicates domestic sewage pollution, found in sites $\mathrm{S}_{4}, \mathrm{~S}_{5}$ and $\mathrm{S}_{6}$.

3.7 Total Hardness (TH)

Hardness is the property of water which prevents lather formation with soap and increases the boiling point of water. It mainly depends on the amount of $\mathrm{Ca}$ or $\mathrm{Mg}$ salts or both. The hardness values ranges from $13.83 \mathrm{mg} / \mathrm{l}$ to $24.58 \mathrm{mg} / \mathrm{l}$ and $123 \mathrm{mg} / \mathrm{l}$ in $\mathrm{S}_{7}$.

3.8. Total Alkalinity (TA)

Alkalinity of water is defined as the ionic concentration, which can neutralize the hydrogen ions. Phenolphthalein alkalinity value is zero, indicating the absence of any carbonate and hydroxyl ions. Here the bicarbonate alkalinity is expressed as the total alkalinity and the values ranges from $9.92 \mathrm{mg} / \mathrm{l}$ to $20.92 \mathrm{mg} / \mathrm{l}$ and $27.5 \mathrm{mg} / \mathrm{l}$ was observed in $\mathrm{S}_{7}$. They were within the permissible limit $(600 \mathrm{ppm})$ and also however, little abnormal values of alkalinity are not harmful to human beings [15]. Its presence is desirable because of its buffering action in the receiving streams which is required for safe disposal of waste water.

3.9. Sodium $\left(\mathrm{Na}^{+}\right)$

Sodium concentration of the water samples were in the range of $2.29 \mathrm{mg} / 1$ to $18.25 \mathrm{mg} / \mathrm{l}$ and $243.57 \mathrm{mg} / \mathrm{l}$ in $S_{7}$. Sodium is important for both agricultural and domestic use of water. In drinking water its presence is harmful to persons suffering from cardiac, renal and circulatory diseases. Its high concentration is toxic to plants.[16]

3.10. Potassium $\left(\mathrm{K}^{+}\right)$

Potassium content of the water samples were in the range of $0.95 \mathrm{mg} / \mathrm{l}$ to $5.91 \mathrm{mg} / \mathrm{l}$ and $20.98 \mathrm{mg} / \mathrm{l}$ in $\mathrm{S}_{7}$. The major source of potassium in fresh water is due to weathering of rocks, but the quantity increases in polluted water due to disposal of waste water.

\subsection{Chloride $\left(\mathrm{Cl}^{-}\right)$}

Chloride is normally the most dominant anion in water. In surface water it originates from both natural and anthropogenic activities such as dissolution of salt deposits, use of inorganic fertilizers, landfill, animal feed etc. Chlorides are harmful in irrigation water and are generally more toxic than sulphate to plants.[16] Chloride values were found in the range of $16.41 \mathrm{mg} / \mathrm{l}$ to $99.25 \mathrm{mg} / \mathrm{l}$ and $765.33 \mathrm{mg} / \mathrm{l}$ in $\mathrm{S}_{7}$.

3.12.Nitrate $\left(\mathrm{NO}^{3-}\right)$

Nitrate values were in the range of $0.34 \mathrm{mg} / 1$ to $1.10 \mathrm{mg} / \mathrm{l}$ and $0.75 \mathrm{mg} / \mathrm{l}$ in $\mathrm{S}_{7}$. Surface water is normally contaminated by sewage and other wastes rich in nitrates. Nitrate pollution will cause Eutrophication, which 
Assessment on the characteristics of river kodayar with reference to Physico-chemical parameters reduces the water quality [16]. Even though the values not exceed the permissible limit, the sites $\mathrm{S}_{3}, \mathrm{~S}_{,} \mathrm{S}_{5}$ and $\mathrm{S}_{6}$ were expected to increase in future which was evident from their nitrate values $(0.96,1.10$ and 1.06$)$. This is due to the disposal of animal wastes and hospital wastes directly in to the water.

3.13.Phosphate $\left(\mathrm{PO}_{4}{ }^{3-}\right)$

Phosphate may occur in surface water as a result of domestic sewage, detergents and agricultural effluents with fertilizers. Phosphate values were in the range of $0.14 \mathrm{mg} / \mathrm{l}$ to $0.35 \mathrm{mg} / \mathrm{l}$. The main environmental impact associated with phosphate pollution is Eutrophication [16].

3.14. Sulphate $\left(\mathrm{SO}_{4}{ }^{2-}\right)$

Sulphate occurs naturally in water as a result of leaching from gypsum and other minerals. Discharge of wastes tends to increase its concentration. Sulphate ions may cause the precipitation of Calcium ions and lead to Sodium poisoning of plants [16]. The concentration of sulphate was in the range of $3.04 \mathrm{mg} / \mathrm{l}$ to $13.5 \mathrm{mg} / \mathrm{l}$ and $58.45 \mathrm{mg} / \mathrm{l}$ in $\mathrm{S}_{7}$. Though they were within the permissible limit, its concentration is high in sites $\mathrm{S}_{4}, \mathrm{~S}_{5}$ and $\mathrm{S}_{6}$, which is due to the disposal of wastes from hospitals, agricultural lands and also animal wastes.

\section{Conclusion}

The results from the data analysis showed that the Physico-chemical parameters are within the water quality standards and the quality of water is good. But in sites $\mathrm{S}_{4}, \mathrm{~S}_{5}$ and $\mathrm{S}_{6}$ few parameters $\left[\mathrm{SO}_{4}{ }^{2-}, \mathrm{NO}^{3-}, \mathrm{PO}_{4}{ }^{3-}\right]$ are found to be increasing, which is due to the discharge of domestic wastes, animal wastes, hospital wastes and also effluents from small cottage industries. As the site $\mathrm{S}_{7}$ is an estuary, it is mainly used only for irrigation purposes. But this study shows that the concentration of $\mathrm{Na}, \mathrm{Cl}^{-}, \mathrm{SO}_{4}{ }^{2-}, \mathrm{NO}^{3-}$ and $\mathrm{PO}_{4}{ }^{3-}$ are increasing, which affects the quality of water for irrigation and also may affect the nearby wells in future.

As we know, once a trend in pollution sets in, it generally accelerates to cause greater deterioration. So few years from now, serious water quality deterioration could take place. Hence rapid and reliable monitoring measures are essential for keeping a close watch on water quality and health environment.

Table-I Average values of the physic-chemical parameters of water samples from various stations

\begin{tabular}{|c|c|c|c|c|c|c|c|c|c|c|}
\hline \multirow{3}{*}{$\begin{array}{l}\text { SI } \\
\mathbf{N} \\
\mathbf{0} \\
\mathbf{1}\end{array}$} & \multirow{3}{*}{$\begin{array}{l}\text { Parameter } \\
\text { s } \\
\text { Temperatur } \\
\text { e }\end{array}$} & \multirow{2}{*}{$\begin{array}{c}\text { WH } \\
\mathbf{O}\end{array}$} & \multirow{2}{*}{ ISI } & \multicolumn{7}{|c|}{ Sampling stations } \\
\hline & & & & $\mathrm{S}_{1}$ & $\mathrm{~S}_{2}$ & $\mathrm{~S}_{3}$ & $\mathrm{~S}_{4}$ & $\mathrm{~S}_{5}$ & $\mathrm{~S}_{6}$ & $\mathrm{~S}_{7}$ \\
\hline & & - & $\begin{array}{lll}- & \text { r }\end{array}$ & 30 & 29.7 & 29.9 & 29.1 & 28.9 & 28.7 & 28.7 \\
\hline 2 & $\mathrm{pH}$ & $7-8.5$ & $\begin{array}{c}6.5- \\
8.5\end{array}$ & 7.01 & 7.03 & 7.06 & 7.15 & 7.23 & 7.27 & 7.4 \\
\hline 3 & EC & 1400 & & 50.33 & 93.25 & $\begin{array}{c}109.4 \\
2\end{array}$ & 112.42 & $\begin{array}{c}127.5 \\
8\end{array}$ & 414.45 & 4236.67 \\
\hline 4 & TDS & 1000 & 500 & 48.74 & 64.03 & 64.21 & 71.67 & 73.72 & 179.44 & 1156.46 \\
\hline 5 & DO & ---- & 5.0 & 5.9 & 5.33 & 5.47 & 5.56 & 4.84 & 5.47 & 4.71 \\
\hline 6 & BOD & --- & --- & 3.21 & 2.64 & 2.45 & 3.06 & 2.29 & 3.16 & 1.98 \\
\hline 7 & $\mathrm{TH}$ & 500 & 300 & 13.83 & 18.33 & 18.67 & 19.83 & 19.67 & 24.58 & 123 \\
\hline 8 & TA & 120 & 200 & 9.92 & 12.83 & 14.42 & 16.75 & 16.33 & 20.92 & 27.5 \\
\hline 9 & $\mathrm{Na}$ & 200 & 200 & 2.29 & 4.84 & 4.49 & 4.55 & 5.14 & 18.25 & 243.57 \\
\hline 10 & K & -- & -- & 0.95 & 1.77 & 1.87 & 1.88 & 1.92 & 5.91 & 20.98 \\
\hline 11 & $\mathrm{Cl}^{-}$ & 250 & 250 & 16.41 & 20.68 & 22.31 & 26.1 & 28.39 & 99.25 & 765.33 \\
\hline 12 & $\mathrm{NO}^{3-}$ & $45-50$ & 45 & 0.34 & 0.77 & 0.96 & 1.10 & 1.41 & 1.07 & 0.75 \\
\hline 13 & $\mathrm{PO}_{4}{ }^{3-}$ & -- & -- & 0.21 & 0.14 & 0.33 & 0.27 & 0.81 & 0.35 & 0.35 \\
\hline 14 & $\mathrm{SO}_{4}^{2-}$ & 150 & 150 & 3.25 & 3.09 & 5.68 & 7.79 & 4.76 & 13.5 & 58.45 \\
\hline
\end{tabular}

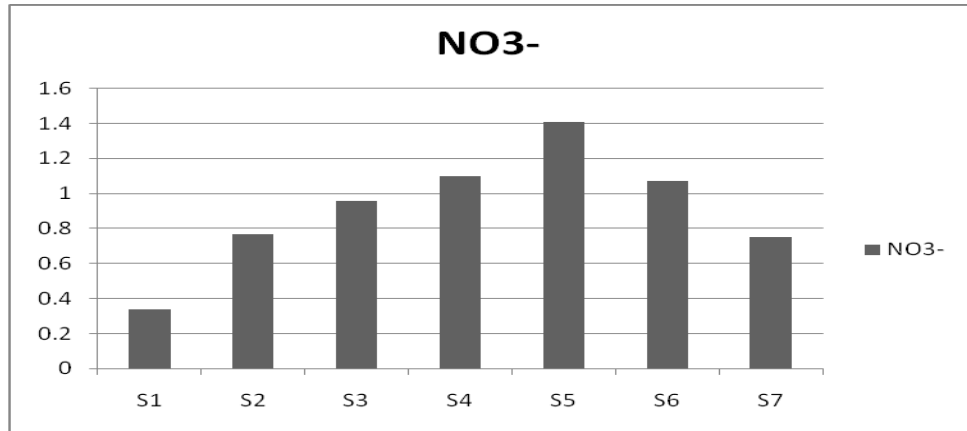

Graph:I showing variations in $\mathrm{NO}_{3}{ }^{-}$values in seven stations 


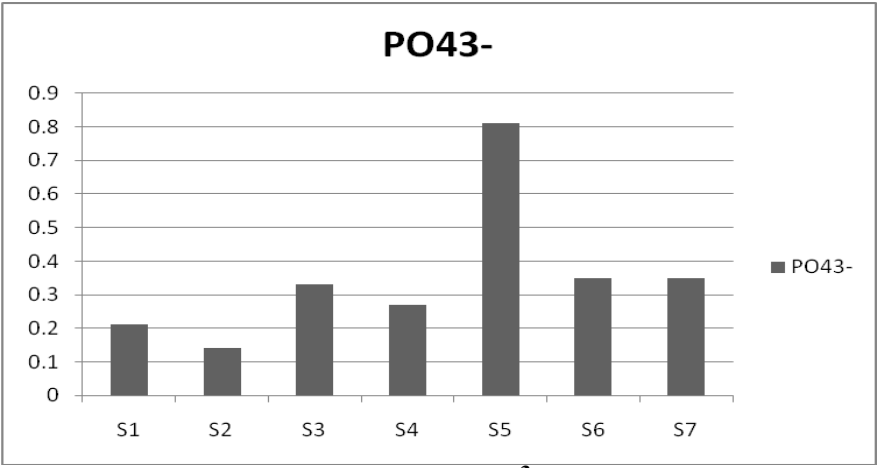

\section{Graph:II showing variations in $\mathrm{PO}_{4}{ }^{3-}$ values in seven stations}

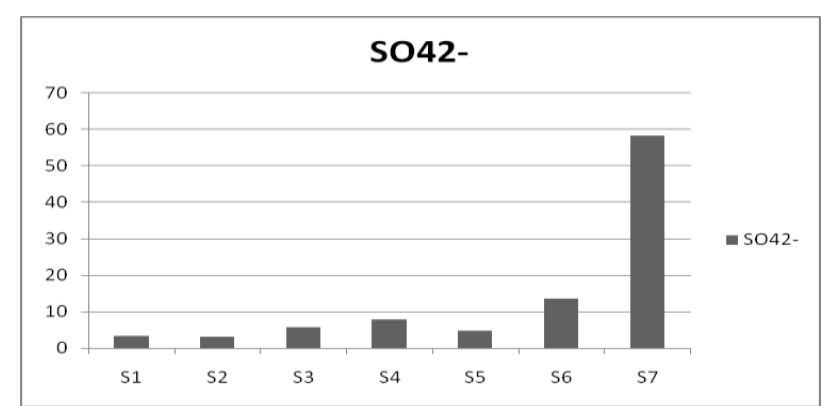

\section{Graph:III showing variations in $\mathrm{SO}_{4}{ }^{2-}$ values in seven stations}

\section{References}

[1] S.Julie Ranee and S.Vasantha; Physico-chemical analysis of borewell water samples of Anaiyur area in Madurai district, TamilNadu, India, J.Curr.Sci. 15(2): 403-408.

[2] Raja R E, Lydia Sharmila, Princy Merlin, Christopher G, Physico-Chemical Analysis of some Ground water samples of Kotputli Town, Jaipur, Rajasthan, Indian J Environ. Prot., 22(2), 137, (2002).

[3] Elizabeth K.M. and Premnath Naik L, Effect of polluted water on human health. Poll.res., 24(2), 337-340, (2005).

[4] Vijender Singh; Physico-chemical examination of water, Sewage and Industrial effluents, Res.J.chem and ENV, 10(3), 62-66(2006).

[5] Arunbh Mishra and Vasishta Bhatt; Physico-Chemical and Microbiological analysis of Under Ground Water in V.V. Nagar and nearby places of Anand District, Gujarat, India, E-J. chem., 5(3), 487-492, (2008).

[6] World Health Organization, guidelines for drinking water quality-I Recommendations $2^{\text {nd }}$ Ed. Geneva WHO. (1993).

[7] APHA AWWA WEF. standard methods for the examination of water and waste water 20 ${ }^{\text {th }}$ Ed. Washington DC (1998).

[8] standard methods for the examination of water and waste water American Public Health Association $17^{\text {th }}$ Ed., Washington DC (1999).

[9] Trivedy R K and Goel P K; Chemical and Biological methods for water pollution studies, Environmental Publication, Karad. (1986).

[10] Manivaskam N., Physico chemical examination of water sewage and industrial effluents $5^{\text {th }}$ Ed., Pragati Prakashan Meerut., (2005).

[11] Sudhir Dahiya and Amarjeet kaur, Physico chemical characteristics of underground water in rural areas of tosham subdivisions, Bhiwani district, Haryana, J.Environ Poll., 6(4), 281, (1999).

[12] Ayedun H, Umar, Assessment of ground water contamination by toxic metals in south west Nigeria, Indian J.Sci.Technol., 4(7), 820-823, (2011).

[13] Kavita Parmar and Vineeta Parmar, Evaluation of water quality Index for drinking water purposes of river Subernarekha in Singhbhum District, International Journal of Environmental Sciences, 1(1), 77-81, (2010).

[14] Tapan Routh and Gupta R.K, Assessment of water quality and self purification process in River Sai at Bela Pratapgarh, (Environment and its challenges, Chapter 31, P.No. 445-463).

[15] T.B.Singh, Indhu Bala and D.Singh, Poll.Res., 18(1), 111, (1999).

[16] HEC (1972), water quality determinations Vol., 11, 1HD series, corps of Engineers, U.S.Army, Davis, California, USA 